\title{
Water-Borne ZnO/Acrylic Nanocoating: Fabrication, Characterization, and Properties
}

\author{
Tien Viet Vu ${ }^{1}$, Thien Vuong Nguyen ${ }^{2,3, *}$, Mohammad Tabish ${ }^{4} \mathbb{D}$, Sehrish Ibrahim ${ }^{5}$, Thi Huong Thuy Hoang ${ }^{6}$,

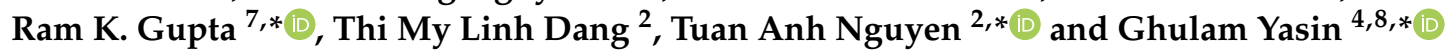

1 Faculty of Chemical Technology, Hanoi University of Industry, Bac Tu Liem, Hanoi 143510, Vietnam; vuviet.tphn@gmail.com

2 Institute for Tropical Technology, Vietnam Academy of Science and Technology, Hanoi 122300, Vietnam; dangthimylinh.lhda58@gmail.com

3 Vietnam Academy of Science and Technology, Graduate University of Science and Technology, 18 Hoang Quoc Viet, CauGiay, Hanoi 122300, Vietnam

4 State Key Laboratory of Chemical Resource Engineering, College of Materials Science and Engineering, Beijing University of Chemical Technology, Beijing 100029, China; tabish.5000@buct.edu.cn

5 Department of Zoology, University of Education, Lahore, Punjab 54770, Pakistan; sehrish.ibrahim@yahoo.com

6 Hong Duc University, 565 Quang Trung, Dong Ve, Thanh Hoa 4000, Thanh Hoa Province, Vietnam; hhthuyhd77@gmail.com

7 Kansas Polymer Research Center, Department of Chemistry, Pittsburg State University, Pittsburg, KS 66762, USA

8 Institute for Advanced Study, College of Physics and Optoelectronic Engineering, Shenzhen University, Shenzhen 518060, China

check for updates

Citation: Vu, T.V.; Nguyen, T.V.; Tabish, M.; Ibrahim, S.; Hoang, T.H.T.; Gupta, R.K.; Dang, T.M.L.; Nguyen,

T.A.; Yasin, G. Water-Borne

$\mathrm{ZnO} /$ Acrylic Nanocoating Fabrication, Characterization, and Properties. Polymers 2021, 13, 717. https://doi.org/10.3390/ polym13050717

Academic Editor: Cornelia Vasile

Received: 6 February 2021

Accepted: 24 February 2021

Published: 26 February 2021

Publisher's Note: MDPI stays neutral with regard to jurisdictional claims in published maps and institutional affiliations.

Copyright: (c) 2021 by the authors. Licensee MDPI, Basel, Switzerland. This article is an open access article distributed under the terms and conditions of the Creative Commons Attribution (CC BY) license (https:/ / creativecommons.org/licenses/by/ $4.0 /)$.
* Correspondence: vuongvast@gmail.com (T.V.N.); ramguptamsu@gmail.com (R.K.G.); ntanh@itt.vast.vn (T.A.N.); yasin@mail.buct.edu.cn (G.Y.)

Abstract: This work aims to explore how $\mathrm{ZnO}$ nanoparticles enhance the mechanical, photoaging, and self cleaning properties of water borne acrylic coating. Micro/nano ZnO particles (at $2 \mathrm{wt} . \%$ of total solid resin) were dispersed into the acrylic polymer matrices using ultrasonication to understand the effect of the size of the coating properties. The effect of $\mathrm{ZnO}$ particles on the properties of composite coatings ( $25 \mu \mathrm{m}$ of thick) have been evaluated through various tests, such as abrasion measurement, ultraviolet/condensation (UV/CON) weathering aging, and methylene blue self cleaning. Experimental data indicated that the incorporation of $\mathrm{ZnO}$ particles enhanced both abrasion resistance and methylene blue removal efficiency of the water borne acrylic coatings, with nano $\mathrm{ZnO}$ particles being the best. However, the weathering degradation of nanocomposite coatings was more severe as compared to the coating with micro $\mathrm{ZnO}$ (at the same $\mathrm{ZnO}$ content).

Keywords: acrylic polymer; micro-ZnO; nano-ZnO; nanocomposite coating; photocatalytic; weathering aging; self-cleaning

\section{Introduction}

Water-borne acrylic paints are widely used to protect and decorate architectural constructions, since they have many advantages, for instance, a low percentage of volatile organic compounds, easy operation, cost-saving, good weathering resistance [1-3]. However, the drawback of this kind of paint is that it is prone to mold growth and dirt clinging. To address this problem, the manufacturers usually add some additives to paint formulations, such as Rocima ${ }^{\mathrm{TM}} 363$, Rocima ${ }^{\mathrm{TM}} 623$, etc. These chemicals are harmful to humans and the environment. Hence, finding alternatives to these toxic substances is considered significant for the interest of researchers and socio-economic development [4-10].

In recent decades, inorganic nanoparticles have been considered as the essential additives to enhance the properties or provide new/multifunctional properties to organic and various nanocoatings [11-17]. Nanoparticles have attracted considerable research interest due to their unique properties, arising from the quantum confinement effect and 
very large surface-to-volume ratios. Similar to other semiconductor oxides, like $\mathrm{TiO}_{2}$, $\mathrm{ZnO}$ could exhibit photocatalytic activity when used in the coating. However, most published works only focused on the micro-sized $\mathrm{ZnO}$ particles, with a very limited photocatalytic behavior in the coating system. In the case of the nanocomposite coating, their antimicrobial activity and self-cleaning ability could be achieved, with nano-ZnO being the most promising and effective photocatalyst [18-21]. As reported, after absorbing $\mathrm{UV}$ radiation, an electron of $\mathrm{ZnO}$ at the valence band jumps into the conduction band, creating an $\mathrm{h}^{+}$hole [22]. Then, the $\mathrm{e}^{-} / \mathrm{h}^{+}$pairs move to the surface of the particles, where they can recombine to each other or react with oxygen and water to form the ${ }^{\bullet} \mathrm{OH}$ radicals.

The newly generated ${ }^{\bullet} \mathrm{OH}$ radicals initiate the decomposition reactions of bacteria and dirt growing on the surface or inside the coatings. Concurrently, these ${ }^{\bullet} \mathrm{OH}$ radicals can play a role in promoting the aging of the coatings $[19,23]$. Under the action of weathering factors, outdoor coatings are significantly degraded [24-26]. The supplement of additives can increase or reduce the weathering resistance of the coatings, depending on their characteristics $[20,27-31]$.

In this study, the impact of $\mathrm{ZnO}$ particles on the properties of composite coatings has been evaluated through various tests, such as the falling sand abrasion, IR, UV-vis, FE-SEM analysis, weight loss, and the self-cleaning function for methylene blue removal.

\section{Materials and Methods}

\subsection{Materials}

Dispersion acrylic polymer PLEXTOL R 4152 with a solid content of $49 \pm 1 \mathrm{wt} . \%$ was received from Synthomer (Essex, UK). Texanol (2,2,4-trimethyl-1,3-pentanediol monoisobutyrate) was obtained from the Dow Chemical Company (Bangkok, Thailand). Nano-ZnO particles $(<100 \mathrm{~nm} ; \geq 99.0 \%)$ and micro-ZnO particles $(>10 \mu \mathrm{m} ; \geq 99.0 \%)$ were supplied by Sigma Aldrich (Singapore).

\subsection{Coating Fabrication}

Texanol (3 wt.\%) was used as a coalescing agent (Dow Chemical Company, Bangkok, Thailand). The used content of nano-ZnO or micro- $\mathrm{ZnO}$ was $2 \mathrm{wt} \%$ (according to the optimal content of nanoparticles in a coating formulation based on our previously published papers [19,32]). The distilled water content was $20 \mathrm{wt} . \%$ (by weight on total solid resin). These paint formulations were prepared by the ultrasonic vibration method in a TPC 25 bath (Bronschhofen, Switzerland) for $2 \mathrm{~h}$ to ensure that the $\mathrm{ZnO}$ nanoparticles were dispersed the best in the dispersion acrylic polymer system. After that, they were coated on the glass plates using a Quadruple Film Applicator (Erichsen model 360, Hemer, Germany) to obtain paint films with a thickness of approximately $25 \mu \mathrm{m}$ (see Scheme 1). For IR and UV-vis analysis, the dried paint films were removed and attached to aluminum windows.

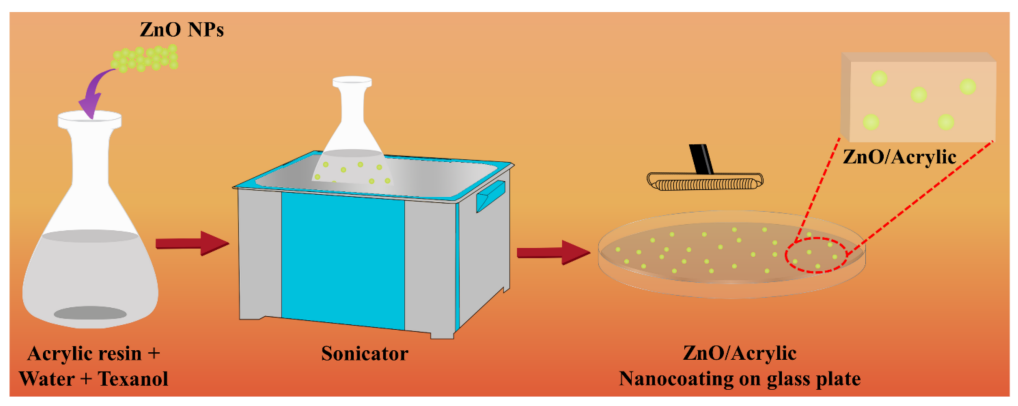

Scheme 1. Schematic illustration of the $\mathrm{ZnO} /$ Acrylic nanocoating fabrication.

\subsection{Coating Characterization}

Determination of abrasion resistance: The abrasion resistance of the paint samples was examined by previously published methods [33]. According to the standard ASTM D968, the abrasion test was performed using the sand falling methods. The abrasion tester 
and silica sand were utilized, and the abrasion resistance (A, litres per mil) was calculated with help of Equation (1).

$$
A_{\text {volume }}=V / T
$$

where $V$ is the volume of abrasive (L) and $T$ is the coating thickness (mils).

Morphology analysis: The dispersion of nano- $\mathrm{ZnO}$ and micro-ZnO particles in the coatings was analyzed by a scanning electron microscope S-4800 (FE-SEM, Hitachi, Tokyo, Japan).

IR analysis: The chemical changes of the coatings during the aging process were studied by IR analysis in an FT-IR spectrometer (NEXUS 670 from Nicolet, Waltham, MA, USA). The quantitative analysis of the changes in the functional groups was performed following the reported method [20]. By making the ratio of the IR absorbance at the corresponding wavenumber of the sample before $\left(D_{o}\right)$ and after $\left(D_{t}\right)$ aging cycles, the remaining functional groups were determined, expressed in Equation (2):

$$
\text { Remaining group }(\%)=\left(D_{t} / D_{o}\right) \times 100
$$

UV-vis analysis: The UV-vis spectra of the initial coatings as well as the coatings covered by methylene blue before and after $12 \mathrm{~h}$ of $\mathrm{UV}$ radiation exposure were determined in a UV-vis spectrophotometer (GBC, CINTRA 40, Austin, TX, USA).

Weight loss: The changes in weight of the coatings impacted by the accelerated weathering environment were measured as presented in our previous work [34]. The weight loss $\left(\Delta m_{t}\right)$ of the coatings after accelerated WT was determined as the difference between the weights of the samples (dried in a vacuum oven at $50{ }^{\circ} \mathrm{C}$ until the constant weight) before $\left(m_{0}\right)$ and after $\left(m_{t}\right)$ the aging process, by Equation (3):

$$
\Delta m_{t}=\left[\left(m_{0}-m_{t}\right) / m_{0}\right] \times 100
$$

\subsection{Weathering Aging Test}

The coatings for the weathering aging test were exposed to the radiation of UVA340 fluorescent lamps in ultraviolet/condensation (UV/CON) equipment (model UC-327-2, Chicago, IL, USA), according to the standards ASTM D-4587-05. Each test cycle consisted of $8 \mathrm{~h}$ of $\mathrm{UV}$ exposure at $60^{\circ} \mathrm{C}$ and $4 \mathrm{~h}$ of condensate water exposure at $50{ }^{\circ} \mathrm{C}$.

\subsection{Self-Cleaning Test}

The methylene blue solution ( $0.0162 \mathrm{~g}$ of methylene blue dissolved in $20 \mathrm{~mL}$ of ethanol) was prepared as the published work [5]. Then, this solution was coated on the paint films by a Quadruple Film Applicator (Erichsen model 360, Hemer, Germany) using a slot of $30 \mu \mathrm{m}$. After being dried, the samples were exposed to UV light in the absence of condensation water to make sure that methylene blue was not washed out during the test.

\section{Results and Discussion}

\subsection{Effect of ZnO Particles on the Mechanical Property of a Water-Borne Acrylic Coating}

Figure 1 shows the results of the falling sand abrasion test of the coatings which did not consist of $\mathrm{ZnO}$ particles, containing $2 \mathrm{wt} . \%$ nano- $\mathrm{ZnO}$ and $2 \mathrm{wt} . \%$ micro- $\mathrm{ZnO}$, respectively.

As can be seen from this figure, the addition of $2 \mathrm{wt} . \%$ nano- $\mathrm{ZnO}$ enhanced the abrasion resistance of the coating from $81.3 \mathrm{lit} / \mathrm{mil}$ to $112.5 \mathrm{lit} / \mathrm{mil}$ (corresponding to $38.4 \%$ ), whilst the supplement of $2 \mathrm{wt} . \%$ micro- $\mathrm{ZnO}$ only increased from $81.3 \mathrm{up}$ to $97.2 \mathrm{lit} / \mathrm{mil}$ (equivalent to $19.5 \%$ ). The enhancement of abrasion resistance when adding $\mathrm{ZnO}$ nanoparticles could be attributed to the polymeric bond formed around the hard $\mathrm{ZnO}$ particles [35]. For further explanation, the morphology of the coatings with or without the presence of $\mathrm{ZnO}$ particles is presented in Figure 2, while the morphology of the micro- $\mathrm{ZnO}$ and nano- $\mathrm{ZnO}$ and their respective particle size distribution histogram are shown in Figure 3, which confirms the nano- $\mathrm{ZnO}$ particles had the particle size of $\leq 100 \mathrm{~nm}$, but the micro- $\mathrm{ZnO}$ had a particle size in the range of 100-300 nm. Further, the SEM images of nano-ZnO at 
different magnifications are shown in Figure S1: Supplementary Materials. As can be seen in Figure 2, without $\mathrm{ZnO}$, the neat coating has a homogeneous morphology. In the case of nano- $\mathrm{ZnO}$, the coating shows no sign of nanoparticle agglomeration, leading to the dense structure of the nanocomposite coating, whereas some agglomeration of microparticles is observed when micro- $\mathrm{ZnO}$ is added to the coating matrix. As a result, the nanocomposite coating exhibits a higher abrasion resistance.

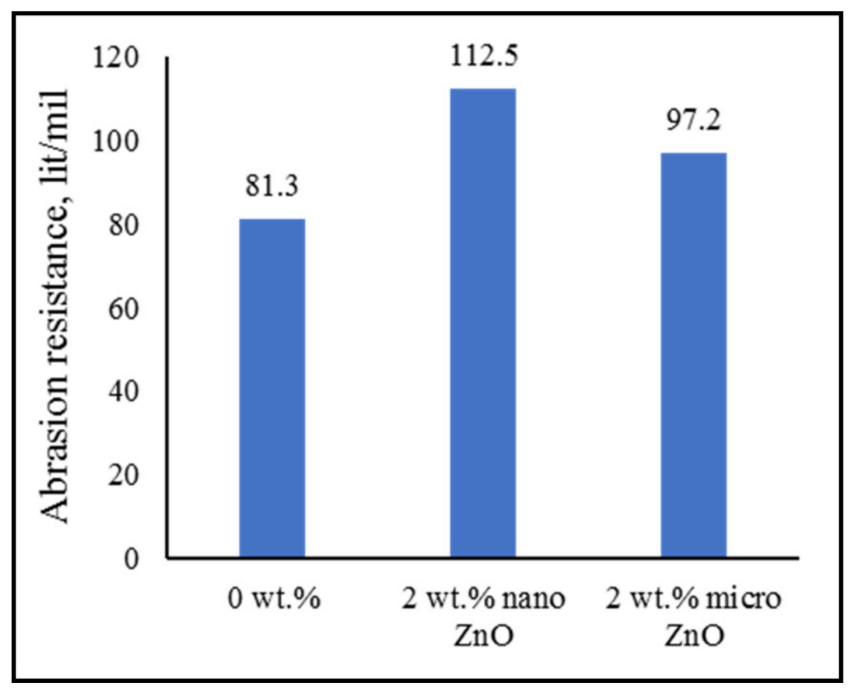

Figure 1. Values of abrasion resistance for the water-borne acrylic coating with or without $\mathrm{ZnO}$ particles.

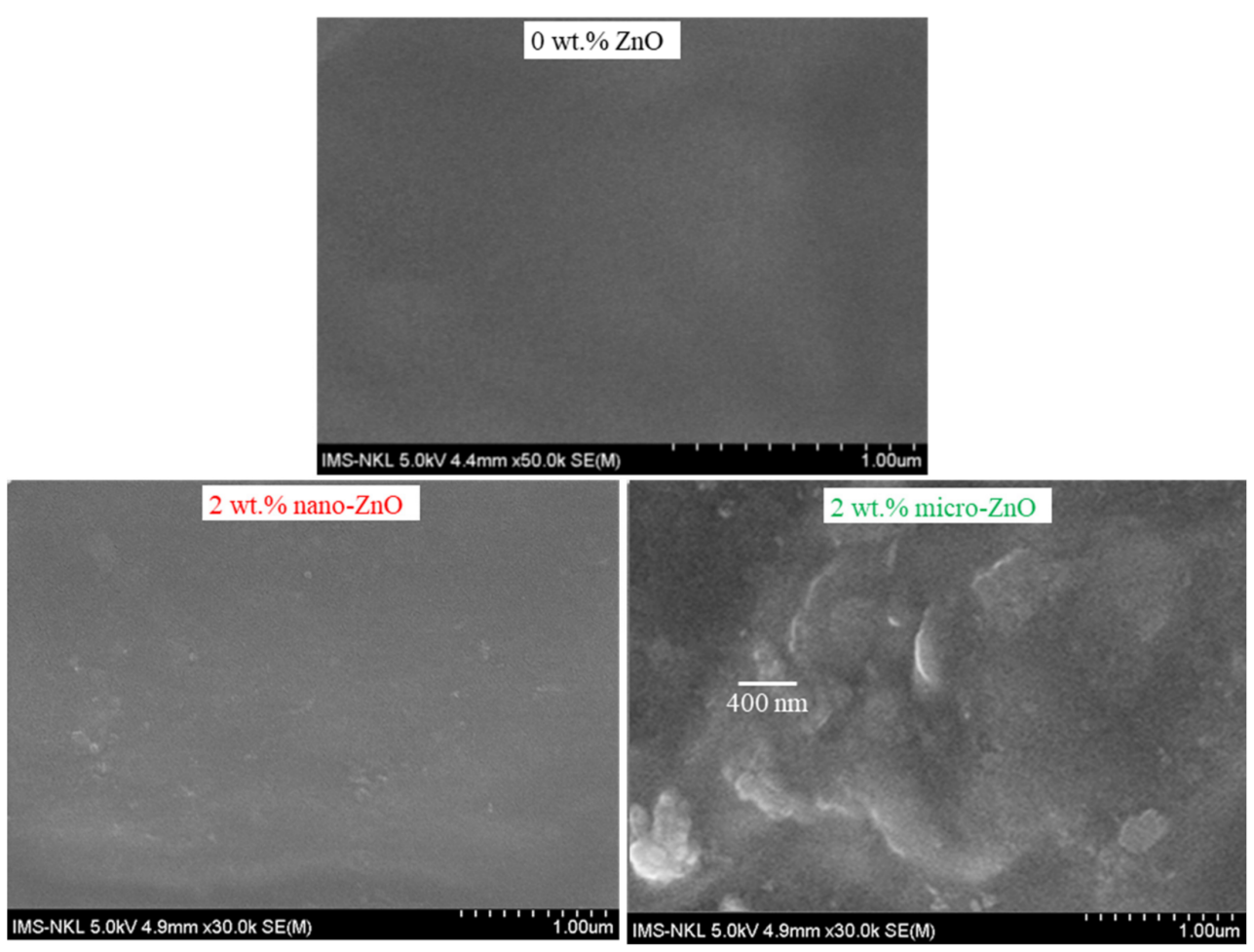

Figure 2. Morphology of acrylic coatings without (0 wt.\% $\mathrm{ZnO}$ ) and with $\mathrm{ZnO}$ particles (2 wt.\% nano- $\mathrm{ZnO}$ and 2 wt.\% micro- $\mathrm{ZnO}$ ). 

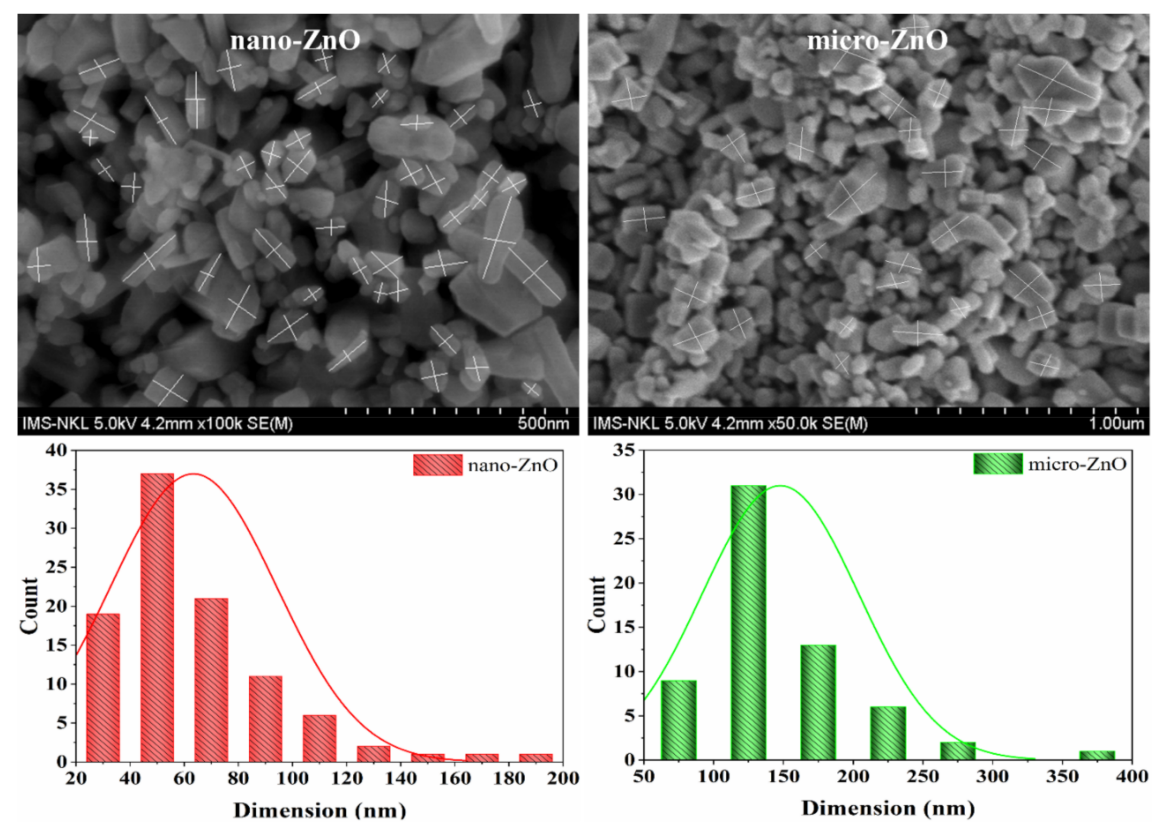

Figure 3. Marked SEM micrograph of the nano-ZnO and micro-ZnO particles for size distribution and their respective particle size distribution histograms.

\subsection{Effect of $\mathrm{ZnO}$ Particles on the Accelerated Weathering Aging of Water-Borne Acrylic Coating}

IR spectra of the coatings without $\mathrm{ZnO}$ particles, with $2 \mathrm{wt} . \%$ nano- $\mathrm{ZnO}$, and with $2 \mathrm{wt} . \%$ micro-ZnO before and after aging (Figure 4) show that under the effect of UV/CON accelerated weathering factors, the peaks at $2950 \mathrm{~cm}^{-1}$ and $1150 \mathrm{~cm}^{-1}$ characterizing the groups of alkane $\mathrm{C}-\mathrm{H}$ and ester $\mathrm{CO}$ in the coatings were reduced. In contrast, the peaks at $3500 \mathrm{~cm}^{-1}$ and $1630 \mathrm{~cm}^{-1}$ characteristic of the groups of $\mathrm{OH}$ and $\mathrm{C}=\mathrm{C}-\mathrm{C}=\mathrm{O}$ (conjugated double bond) increased. Among them, the changes of absorbances characterizing the alkane $\mathrm{C}-\mathrm{H}$ and $\mathrm{C}=\mathrm{C}-\mathrm{C}=\mathrm{O}$ groups are the most obvious rule, so they were chosen to study the changes in the chemical structure of the coatings during aging. The results of the quantitative change analysis of alkane $\mathrm{C}-\mathrm{H}$ groups and conjugated double bonds of the corresponding coatings, mentioned above, during the UV/CON aging process are illustrated in Figure 5.

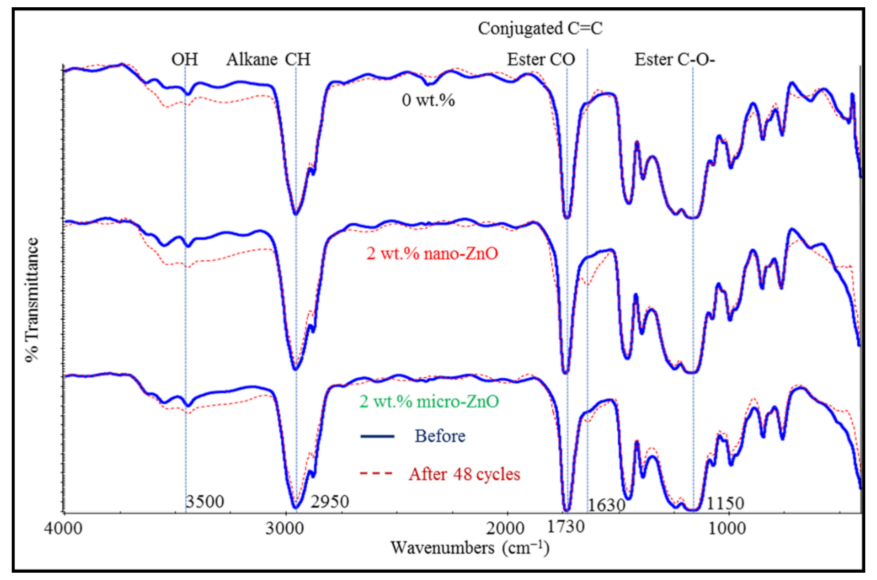

Figure 4. IR spectra of the coatings without $\mathrm{ZnO}$ particles (0 wt.\%), with 2 wt. $\%$ nano- $\mathrm{ZnO}$ and 2 wt. \% micro-ZnO before and after 48 cycles of UV/CON aging. 


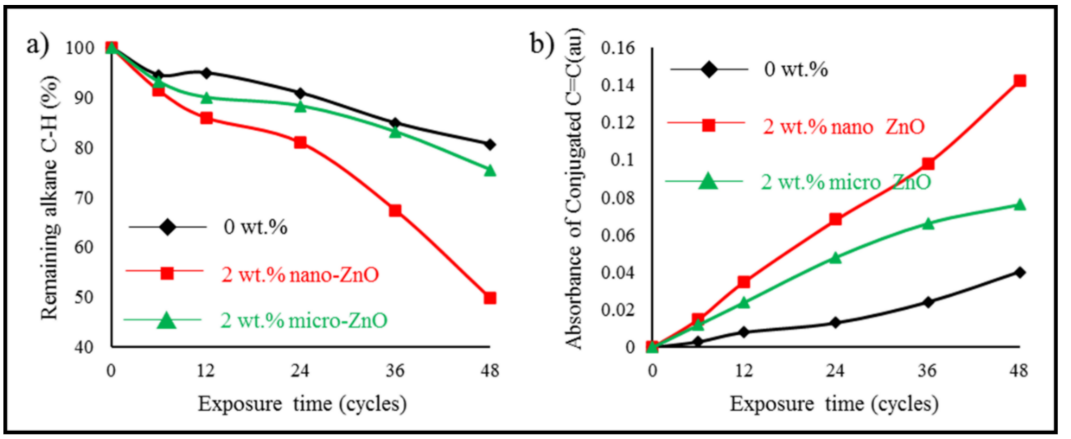

Figure 5. (a) Changes of alkane $\mathrm{C}-\mathrm{H}$ and (b) conjugated $\mathrm{C}=\mathrm{C}$ groups in the coatings with (2 wt. $\%$ ) or without (0 wt.\%) $\mathrm{ZnO}$ particles during the UV/CON aging.

As shown in Figures 4 and 5, under the UV/CON accelerated weathering, the peaks at $2950 \mathrm{~cm}^{-1}$ and $1150 \mathrm{~cm}^{-1}$ characterizing the stretching of alkane $\mathrm{C}-\mathrm{H}$ and ester C-O- in the coatings reinforced by $2 \mathrm{wt} . \%$ nano- $\mathrm{ZnO}$ decreased more strongly than those of the coating containing $2 \mathrm{wt} . \%$ micro-ZnO. In contrast, the peaks at $3500 \mathrm{~cm}^{-1}$ and $1630 \mathrm{~cm}^{-1}$ representing the stretching of $\mathrm{O}-\mathrm{H}$ and $\mathrm{C}=\mathrm{C}-\mathrm{C}=\mathrm{O}$ conjugated double bonds of the coating with nano- $\mathrm{ZnO}$ increased significantly compared to the coating with $\mathrm{ZnO}$ particles in micro size. In the coatings which do not contain $\mathrm{ZnO}$ particles, the alkane $\mathrm{C}-\mathrm{H}$ and ester $\mathrm{C}-\mathrm{O}$ groups decreased, while the $\mathrm{OH}$ and $\mathrm{C}=\mathrm{C}-\mathrm{C}=\mathrm{O}$ groups increased less than those in the coatings containing $\mathrm{ZnO}$ particles. After 48 testing cycles, the contents of alkane $\mathrm{C}-\mathrm{H}$ groups remaining in the coatings without $\mathrm{ZnO}$, with 2 wt.\% nano- $\mathrm{ZnO}$, and with $2 \mathrm{wt}$.\% micro- $\mathrm{ZnO}$ were $80.5 \%, 49.7 \%$, and $75.5 \%$, respectively.

These obtained data suggested that the $\mathrm{ZnO}$ particles play an important role as photocatalysts in promoting the aging process of coatings under UV irradiation, with the nano-ZnO being more severe. To prove this point, the UV-vis spectra of the three coating samples, such as neat coating ( $0 \mathrm{wt} . \%)$ and composite/nanocomposite (2 wt.\%) coatings, have been analyzed and presented in Figure 5. As seen in Figure 5, the absorbance at $375 \mathrm{~nm}$ characterizing the presence of $\mathrm{ZnO}$ particles in the coating is much higher for nano$\mathrm{ZnO}$ than that for micro- $\mathrm{ZnO}$. This result indicated that the nano- $\mathrm{ZnO}$ absorbs much more UV radiation than micro- $\mathrm{ZnO}$, and thus the photocatalytic behavior could be observed more clearly in the nanocomposite coating. The reason why the photocatalytic activity was much stronger with the presence of nano- $\mathrm{ZnO}$ in the coating is the "quantum confinement effect" at the nanoscale (discretization of energy levels), whereas, like bulk matter, the energy bands in micro- $\mathrm{ZnO}$ could be formed by merging adjacent energy levels.

This finding is consistent with the study of Seentrakoon et al. [36] on the roles of $\mathrm{TiO}_{2}$ in the nano and micro scales. It has been explained that the nanoparticles have a much greater specific surface area than the microparticles. Figure 6 also indicates that the coating containing $\mathrm{ZnO}$ nanoparticles is more transparent in the visible light region than that consisting of $\mathrm{ZnO}$ microparticles with the same content. Figure 7 shows the influence of $\mathrm{ZnO}$ particles on the changes in weight of coatings during the aging process. As shown in this figure, during the aging process, the coatings with $\mathrm{ZnO}$ particles (nano$\mathrm{ZnO} / \mathrm{micro}-\mathrm{ZnO}$ ) have a higher value of weight loss than the neat coating, with $2 \mathrm{wt}$.\% nano- $\mathrm{ZnO}$ being the greatest. After 48 cycles, the weight of the coatings without $\mathrm{ZnO}$ particles, with $2 \mathrm{wt} . \%$ nano- $\mathrm{ZnO}$, and $2 \mathrm{wt} . \%$ micro- $\mathrm{ZnO}$ remained $92.6 \%, 77.1 \%$, and $88.2 \%$, respectively. This shows that during the aging process, the bonds in the polymer chain can be broken by photolysis, photooxidation, photocatalytic, and hydrolysis reactions, forming smaller substances. These compounds can be evaporated or washed out in the presence of condensate water. Due to the strongest photocatalytic activity of $\mathrm{ZnO}$ nanoparticles, the nanocomposite has the highest weight loss rate. 


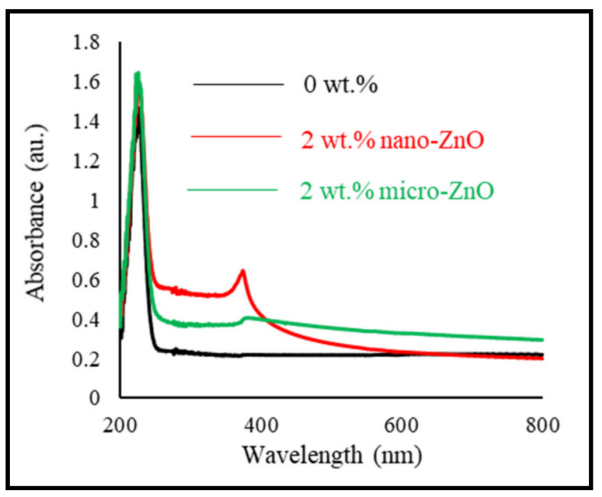

Figure 6. UV-vis spectra of the coatings with (2 wt.\%) or without (0 wt.\%) ZnO particles.

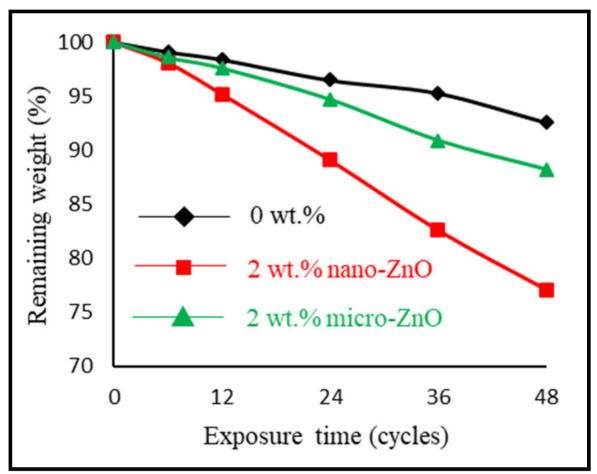

Figure 7. Weight changes of coatings with (2 wt.\%) or without (0 wt. \%) ZnO particles, during the $\mathrm{UV} / \mathrm{CON}$ aging.

\subsection{Self-Cleaning Performance of Water-Borne Acrylic Coating Containing ZnO Particles}

As an industrial dye, methylene blue has been commonly used as artificial dirt to evaluate the photocatalytic efficiency of metal oxides [5]. In the methylene blue removal (self-cleaning ability) test, each coating was irradiated by UV light for $12 \mathrm{~h}$. Figures 8 and 9 present photographs and UV-vis spectra of various coatings in the methylene blue removal test, respectively.

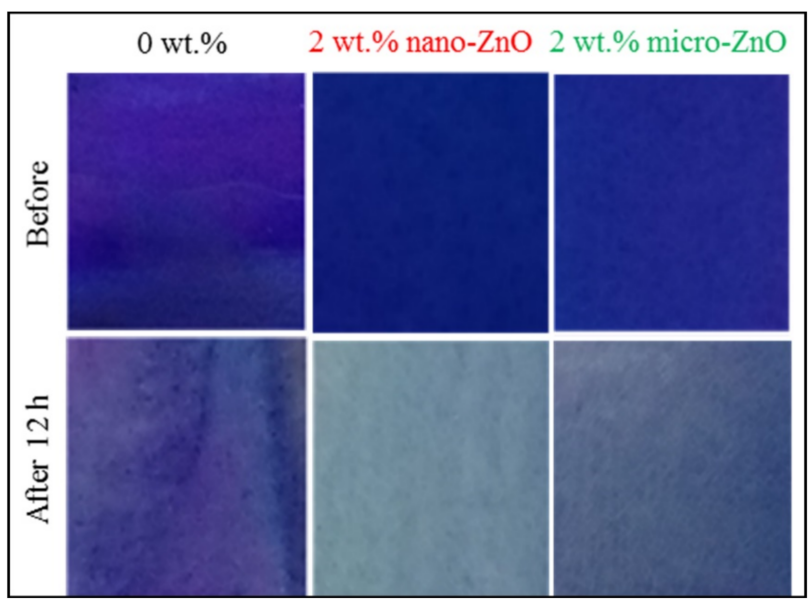

Figure 8. Photographs of methyl blue-contaminated coatings without or without $\mathrm{ZnO}$ particles, before and after $12 \mathrm{~h}$ of UV exposure. 


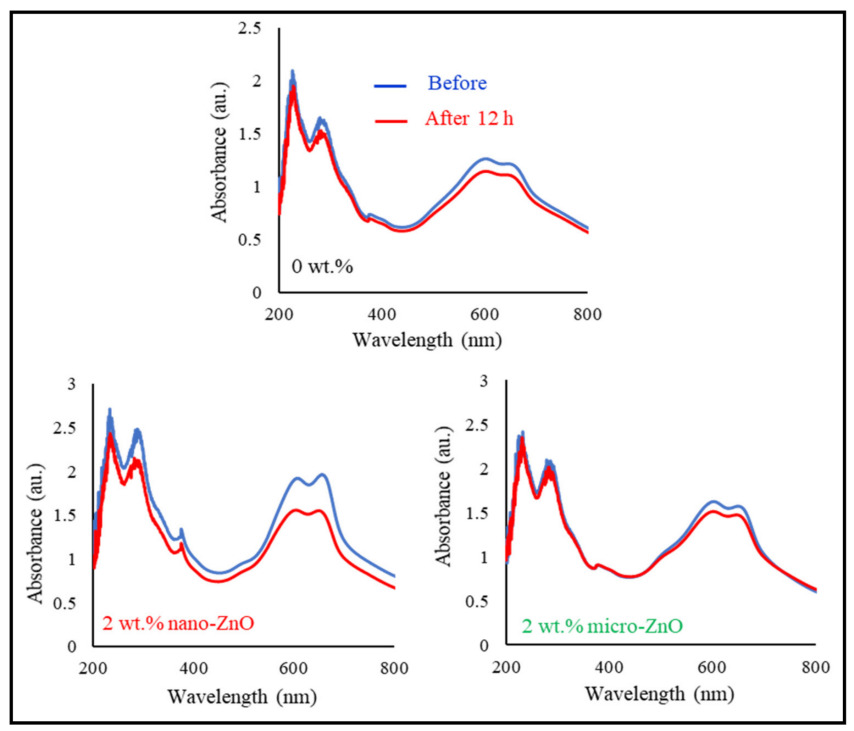

Figure 9. UV-vis spectra of the methyl blue-contaminated coatings with (2 wt.\%) or without (0 wt.\%) $\mathrm{ZnO}$ particles, before and after $12 \mathrm{~h}$ of UV exposure.

As shown in Figure 8, after $12 \mathrm{~h}$ of UV radiation exposure, the methylene blue was decolorized most efficiently by the nanocomposite coating and least efficiently by the neat coating. Similar results were obtained when investigating the UV-vis spectra (Figure 9). After being exposed to $\mathrm{UV}$ radiation for $12 \mathrm{~h}$, the characteristic absorbance of methylene blue in the region of 500-700 $\mathrm{nm}$ decreased most strongly in the case of the coating containing $2 \mathrm{wt} . \%$ nano- $\mathrm{ZnO}$ and most weakly regarding the neat coating.

The fast decolorization and reduction of the characteristic UV absorbance of methylene blue in the case of the coating containing $2 \mathrm{wt} . \%$ nano- $\mathrm{ZnO}$ can be explained by the photocatalytic effect of the nanoparticles that led to the low adhesion of this dye. Hence, the dirt was easily separated from the coating. On the other hand, the photolysis may result in the decomposition of methylene blue as reported in the literature [37-40].

The obtained results experimentally proved that the photocatalytic activity of nano$\mathrm{ZnO}$ was significantly stronger than that of micro- $\mathrm{ZnO}$.

\section{Conclusions}

The effect of micro-/nano-ZnO particles on the properties of water-borne acrylic coatings was systematically investigated. The results showed that the incorporation of $\mathrm{ZnO}$ particles increased both the abrasion resistance and the methylene blue removal efficiency of the water-borne acrylic coatings, with nano- $\mathrm{ZnO}$ particles being the best. The dispersion of nanoparticles through sonication showed a complete dispersibility, with no polymer chain destruction observed in IR and UV-vis spectra. However, the weathering degradation of nanocomposite coatings was more severe as compared to the coating with micro- $\mathrm{ZnO}$. Our finding indicates the promising use of nano- $\mathrm{ZnO}$ in multifunctional water-borne acrylic coatings.

Supplementary Materials: The following are available online at https:/ /www.mdpi.com/2073-436 0/13/5/717/s1, Figure S1: SEM micrograph of the nano-ZnO particles at different magnifications.

Author Contributions: Data curation, M.T.; formal analysis, S.I. and R.K.G.; investigation, T.H.T.H. and T.M.L.D.; project administration, T.V.N. and T.A.N.; writing — original draft, T.V.V.; writingreview \& editing, G.Y. All authors have read and agreed to the published version of the manuscript.

Funding: No funding support.

Institutional Review Board Statement: Not applicable.

Informed Consent Statement: Not applicable. 
Data Availability Statement: The data presented in this study are available on request from the corresponding author.

Conflicts of Interest: The authors declare no conflict of interest.

\section{References}

1. Izmitli, A.; Ngunjiri, J.; Lan, T.; Pacholski, M.L.; Smith, R.; Langille, M.; Roggow, T.; Henderson, K.; Kalantar, T.; Manna, J. Impact of silicone additives on slip/mar performance and surface characteristics of waterborne acrylic coatings. Prog. Org. Coat. 2019, 131, 145-151. [CrossRef]

2. Saha, S.; Kocaefe, D.; Krause, C.; Larouche, T. Effect of titania and zinc oxide particles on acrylic polyurethane coating performance. Prog. Org. Coat. 2011, 70, 170-177. [CrossRef]

3. Cogulet, A.; Blanchet, P.; Landry, V. Evaluation of the impacts of four weathering methods on two acrylic paints: Showcasing distinctions and particularities. Coatings 2019, 9, 121. [CrossRef]

4. Bellotti, N.; Romagnoli, R.; Quintero, C.; Domínguez-Wong, C.; Ruiz, F.; Deyá, C. Nanoparticles as antifungal additives for indoor waterborne paints. Prog. Org. Coat. 2015, 86, 33-40. [CrossRef]

5. Pinho, L.; Rojas, M.; Mosquera, M.J. Ag-SiO $2-\mathrm{TiO}_{2}$ nanocomposite coatings with enhanced photoactivity for self-cleaning application on building materials. Appl. Catal. B Environ. 2015, 178, 144-154. [CrossRef]

6. Yasin, G.; Arif, M.; Mehtab, T.; Lu, X.; Yu, D.; Muhammad, N.; Nazir, M.T.; Song, H. Understanding and suppression strategies toward stable Li metal anode for safe lithium batteries. Energy Storage Mater. 2020, 25, 644-678. [CrossRef]

7. Tabish, M.; Yasin, G.; Anjum, M.J.; Malik, M.U.; Zhao, J.; Yang, Q.; Manzoor, S.; Murtaza, H.; Khan, W.Q. Reviewing the current status of layered double hydroxide-based smart nanocontainers for corrosion inhibiting applications. J. Mater. Res. Technol. 2021, 10, 390-421. [CrossRef]

8. Tabish, M.; Malik, M.U.; Khan, M.A.; Yasin, G.; Asif, H.M.; Anjum, M.J.; Khan, W.Q.; Ibraheem, S.; Nguyen, T.A.; Slimani, Y. Construction of NiCo/Graphene Nanocomposite Coating with Bulges-like Morphology for Enhanced Mechanical Properties and Corrosion Resistance Performance. J. Alloys Compd. 2021, 867, 159138. [CrossRef]

9. Dillon, C.E.; Lagalante, A.F.; Wolbers, R.C. Acrylic emulsion paint films: The effect of solution $\mathrm{pH}$, conductivity, and ionic strength on film swelling and surfactant removal. Stud. Conserv. 2014, 59, 52-62. [CrossRef]

10. Özgenç, Ö. Comparison of durability of wood coatings containing different waterborne acrylic resins and UV absorbers in natural weathering. Drew. Pr. Nauk. Doniesienia Komun. 2020, 62, 47-61.

11. Bui, T.M.A.; Nguyen, T.V.; Nguyen, T.M.; Hoang, T.H.; Nguyen, T.T.H.; Lai, T.H.; Tran, T.N.; Hoang, V.H.; Le, T.L.; Dang, T.C. Investigation of crosslinking, mechanical properties and weathering stability of acrylic polyurethane coating reinforced by $\mathrm{SiO}_{2}$ nanoparticles issued from rice husk ash. Mater. Chem. Phys. 2020, 241, 122445. [CrossRef]

12. Nguyen, T.V.; Nguyen-Tri, P.; Azizi, S.; Dang, T.C.; Hoang, D.M.; Hoang, T.H.; Nguyen, T.L.; Le Bui, T.T.; Dang, V.H.; Nguyen, N.L. The role of organic and inorganic UV-absorbents on photopolymerization and mechanical properties of acrylate-urethane coating. Mater. Today Commun. 2020, 22, 100780. [CrossRef]

13. Yasin, G.; Arif, M.; Mehtab, T.; Shakeel, M.; Khan, M.A.; Khan, W.Q. Metallic nanocomposite coatings. In Corrosion Protection at the Nanoscale; Elsevier: Amsterdam, The Netherlands, 2020; pp. 245-274.

14. Nguyen, V.T.; Tabish, M.; Yasin, G.; Bilal, M.; Nguyen, T.H.; Van, C.P.; Nguyen-Tri, P.; Gupta, R.K.; Nguyen, T.A. A facile strategy for the construction of $\mathrm{TiO}_{2} / \mathrm{Ag}$ nanohybrid-based polyethylene nanocomposite for antimicrobial applications. Nano-Struct. Nano-Obj. 2021, 25, 100671. [CrossRef]

15. Sbardella, F.; Bracciale, M.P.; Santarelli, M.L.; Asua, J.M. Waterborne modified-silica/acrylates hybrid nanocomposites as surface protective coatings for stone monuments. Prog. Org. Coat. 2020, 149, 105897. [CrossRef]

16. Bal, A.; Güçlü, G.; İyim, T.B.; Özgümüş, S. Effects of nanoparticles on film properties of waterborne acrylic emulsions. Polym. Plast. Technol. Eng. 2011, 50, 990-995. [CrossRef]

17. Miklečić, J.; Turkulin, H.; Jirouš-Rajković, V. Weathering performance of surface of thermally modified wood finished with nanoparticles-modified waterborne polyacrylate coatings. Appl. Surf. Sci. 2017, 408, 103-109. [CrossRef]

18. Miklečić, J.; Blagojević, S.L.; Petrič, M.; Jirouš-Rajković, V. Influence of $\mathrm{TiO}_{2}$ and $\mathrm{ZnO}$ nanoparticles on properties of waterborne polyacrylate coating exposed to outdoor conditions. Prog. Org. Coat. 2015, 89, 67-74. [CrossRef]

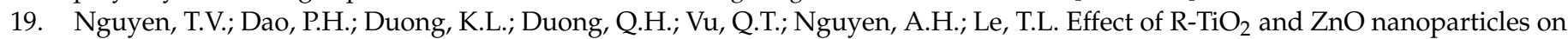
the UV-shielding efficiency of water-borne acrylic coating. Prog. Org. Coat. 2017, 110, 114-121. [CrossRef]

20. Nguyen, T.V.; Dao, P.H.; Nguyen, T.A.; Dang, V.H.; Ha, M.N.; Nguyen, T.T.T.; Vu, Q.T.; Nguyen, N.L.; Dang, T.C.; Nguyen-Tri, P. Photocatalytic degradation and heat reflectance recovery of waterborne acrylic polymer/ZnO nanocomposite coating. J. Appl. Polym. Sci. 2020, 137, 49116. [CrossRef]

21. Javadi, E.; Ghaffari, M.; Bahlakeh, G.; Taheri, P. Photocatalytic, corrosion protection and adhesion properties of acrylic nanocomposite coating containing silane treated nano zinc oxide: A combined experimental and simulation study. Prog. Org. Coat. 2019, 135, 496-509. [CrossRef]

22. Suwanboon, S.; Amornpitoksuk, P.; Randorn, C. Effect of tartaric acid as a structure-directing agent on different $\mathrm{ZnO}$ morphologies and their physical and photocatalytic properties. Ceram. Int. 2019, 45, 2111-2116. [CrossRef]

23. Chen, X.D.; Wang, Z.; Liao, Z.F.; Mai, Y.L.; Zhang, M.Q. Roles of anatase and rutile TiO2 nanoparticles in photooxidation of polyurethane. Polym. Test. 2007, 26, 202-208. [CrossRef] 
24. Hien, L.X.; Vuong, N.T. Study of the influence of the chemical nature on the humid heat, ultraviolet radiation durability of some coatings based on acrylic resins. Vietnam J. Sci. Technol. 2009, 47, 69-75.

25. Mac Van Phuc, N.T.V.; Hung, D.P.; Hiep, N.A.; Van Thanh, T. Accelerated aging of solar heat reflective coating on acrylic emulsion. Vietnam J. Chem. 2016, 54, 286-292.

26. Larché, J.F.; Bussière, P.O.; Gardette, J.L. How to reveal latent degradation of coatings provoked by UV-light. Polym. Degrad. Stab. 2010, 95, 1810-1817. [CrossRef]

27. Fufa, S.M.; Jelle, B.P.; Hovde, P.J. Weathering performance of spruce coated with water based acrylic paint modified with $\mathrm{TiO}_{2}$ and clay nanoparticles. Prog. Org. Coat. 2013, 76, 1543-1548. [CrossRef]

28. Özgenç, Ö.; Durmaz, S.; Şahin, S.; Boyaci, I.H. Evaluation of the weathering resistance of waterborne acrylic-and alkyd-based coatings containing HALS, UV absorber, and bark extracts on wood surfaces. J. Coat. Technol. Res. 2020, 17, 461-475. [CrossRef]

29. Wojciechowski, K.; Zukowska, G.Z.; Korczagin, I.; Malanowski, P. Effect of $\mathrm{TiO}_{2}$ on UV stability of polymeric binder films used in waterborne facade paints. Prog. Org. Coat. 2015, 85, 123-130. [CrossRef]

30. Mirabedini, S.M.; Sabzi, M.; Zohuriaan-Mehr, J.; Atai, M.; Behzadnasab, M. Weathering performance of the polyurethane nanocomposite coatings containing silane treated $\mathrm{TiO}_{2}$ nanoparticles. Appl. Surf. Sci. 2011, 257, 4196-4203. [CrossRef]

31. Bonnefond, A.; González, E.; Asua, J.M.; Leiza, J.R.; Ieva, E.; Brinati, G.; Carella, S.; Marrani, A.; Veneroni, A.; Kiwi, J. Stable photocatalytic paints prepared from hybrid core-shell fluorinated/acrylic/ $\mathrm{TiO}_{2}$ waterborne dispersions. Crystals 2016, 6, 136. [CrossRef]

32. Nguyen, T.V.; Tri, P.N.; Nguyen, T.D.; El Aidani, R.; Decker, C. Accelerated degradation of water borne acrylic nanocomposites used in outdoor protective coatings. Polym. Degrad. Stab. 2016, 128, 65-76. [CrossRef]

33. Le, T.T.; Nguyen, T.V.; Nguyen, T.A.; Nguyen, T.T.H.; Thai, H.; Dinh, D.A.; Nguyen, T.M. Thermal, mechanical and antibacterial properties of water-based acrylic Polymer $/ \mathrm{SiO}_{2}-\mathrm{Ag}$ nanocomposite coating. Mater. Chem. Phys. 2019, 232, 362-366. [CrossRef]

34. Vuong, N.T.; Linh, N.T. The accelerated weathering aging of a water-borne styrene acrylic coating. Vietnam J. Chem. 2016, 54, 139.

35. Kardar, P.; Ebrahimi, M.; Bastani, S. Study the effect of nano-alumina particles on physical-mechanical properties of UV cured epoxy acrylate via nano-indentation. Prog. Org. Coat. 2008, 62, 321-325. [CrossRef]

36. Seentrakoon, B.; Junhasavasdikul, B.; Chavasiri, W. Enhanced UV-protection and antibacterial properties of natural rubber/rutile$\mathrm{TiO}_{2}$ nanocomposites. Polym. Degrad. Stab. 2013, 98, 566-578. [CrossRef]

37. Hoa, T.T.; Hoa, L.T.; Khieu, D.Q.; Son, L.C. Study on photooxydation reaction of methylene blue on nano $\mathrm{TiO}_{2}$ catalyst under the effect of sunlight. Hue Univ. J. Sci. 2011, 65, 88-93.

38. Peter, A.; Mihaly-Cozmuta, A.; Nicula, C.; Mihaly-Cozmuta, L.; Jastrzębska, A.; Olszyna, A.; Baia, L. UV Light-Assisted Degradation of Methyl Orange, Methylene Blue, Phenol, Salicylic Acid, and Rhodamine B: Photolysis Versus Photocatalyis. Water Air. Soil. Pollut. 2016, 228, 41. [CrossRef]

39. Che Ramli, Z.A.; Asim, N.; Isahak, W.N.R.W.; Emdadi, Z.; Ahmad-Ludin, N.; Yarmo, M.A.; Sopian, K. Photocatalytic Degradation of Methylene Blue under UV Light Irradiation on Prepared Carbonaceous. Sci. World J. 2014, 2014, 415136. [CrossRef]

40. Oda, A.M.; Salih, A.; Hadi, S.; Jawad, A.; Sadoon, A.; Fahim, Y.; Fadhil, A. Photocatalytic decolorization of methylene blue dye by zinc oxide powder. J. Babylon. Univ. Pure Appl. Sci. 2014, 22, 2508-2515. 